\title{
EFEKTIVITAS LAYANAN KONSELING KELOMPOK TEKNIK MODELLING DALAM MEMBENTUK KETERAMPILAN KEPEMIMPINAN SISWA
}

\author{
Rapizon Kuswara, Pudji Hartuti, Rita Sinthia \\ Prodi Bimbingan dan Konseling Fakultas Keguruan dan Ilmu Pendidikan \\ Universitas Bengkulu \\ Rapizonkuswara95@gmail.com,pudjihartuti@unib.ac.id, ritasinthia@unib.ac.id
}

\begin{abstract}
ABSTRAK
Penelitian ini bertujuan untuk mengetahui efektivitas layanan konseling kelompok melalui teknik modelling dalam membentuk keterampilan kepemimpian siswa di SMKS 16 Famasi Bengkulu. Metode yang digunakan dalam penelitian ini adalah metode eksperimen dengan desain penelitian one group pre-test dan post-test design. Teknik pengambilan sampel pada penelitinan ini menggunakn teknik purposive sampling. Sampel dalam penelitian ini adalah 7 orang siswa dari kelas X D yang memiliki tingkat keterampilan kepemimpinan rendah dan sangat rendah. Teknik pengumpulan data dalam penelitian ini menggunakan angket. Hasil yang diperoleh dalam penelitian ini menunjukkan keterampilan kepemimpinan meningkat setelah diberikan layanan konseling kelompok dengan teknik modelling. Hal ini terlihat dari hasil pre-test dan post-test $\mathrm{p}=0.018$ maka $\mathrm{p}<0.05$, sehingga dapat disimpulkan Ho ditolak dan Ha diterima. Artinya, terdapat pengaruh yang signifikan keterampilan kepemimpinan siswa sebelum dan sesudah diberikan layanan konseling kelompok dengan teknik modelling.
\end{abstract}

Kata kunci: kepemimpinan, layanan konseling kelompok, modelling

\section{THE EFFECTIVENESS OF GROUP COUNSELING SERVICES THROUGH MODELLING TECHNIQUES IN FORMING LEADERSHIP}

\begin{abstract}
This study aims to determine the effectiveness of group counseling services through modelling techniques in shaping student leadership skills in SMKS 16 Famasi Bengkulu. The method used in this research is experimental method with one group pre-test and post-test design. Sampling technique in this research using purposive sampling technique. The sample in this research is 7 students from class X D who have low leadership skill level and very low. Data collection techniques in this study using a questionnaire. The results obtained in this study showed that leadership skills improved after group counseling service with modelling techniques. It is seen from the results of pre-test and post-test $p=0.018$ then $p$ $<0.05$, so it can be concluded Ho rejected and Ha accepted. Meaning, there are significant influence of student leadership skills before and after being given group counseling services with modelling techniques.
\end{abstract}

Keywords: leadership, group counseling services, modelling 


\section{Pendahuluan}

Masa remaja disebut juga masa untuk menemukan identitas diri (Hurlock, 1980: 208) pencarian indentitas diri tersebut ditandai dengan mencoba hal baru, diantaranya hidup berkelompok bersama teman sebaya. Sebagai makhluk sosial, remaja membutuhkan orang lain untuk dapat tumbuh dan berkembang menjadi manusia yang utuh.

Pada masa ini, sikap remaja cenderung menyerah atau mengikuti opini, pendapat, nilai, kebiasaan, kegemaran, dan keinginan orang lain. Apabila kelompok teman sebaya yang diikuti menampilkan sikap perilaku positif maka kemungkinan besar remaja tersebut akan menampilkan pribadinya yang baik, begitupun sebaliknya. Untuk itulah dibutuhkan sumber daya manusia yang berkualitas. Sumber daya yang berjiwa pemimpin, paling tidak mampu memimpin dirinya sendiri. Dengan berjiwa pemimpin, manusia akan dapat mengelola diri, kelompok, dan lingkungan dengan baik.

Pemimpin adalah seseorang yang mampu mempengaruhi orang lain melalui kewibawaanya dan komunikasi untuk mencapai tujuan (Pahlawan, 2005: 7). Sedangkan menurut Kartono (dalam Anoraga, 2013: 3), pemimpin adalah seorang pribadi yang memiliki kecakapan dan kelebihan disuatu bidang, sehingga dia mampu mempengaruhi orang lain untuk bersama-sama melakukan aktivitas tertentu, demi pencapaian tujuan.

Gordon (dalam Rohidi, 2015: 55), keterampilan adalah kemampuan untuk mengoperasikan pekerjaan secara mudah dan cermat. Sedangkan Nadler (dalam Rohidi, 2015: 56), keterampilan adalah kegiatan yang memerlukan praktek atau dapat diartikan sebagai implikasi dari keterampilan. Menurut Dunnette (dalam Rohidi, 2015: 56), keterampilan adalah kapasitas yang dibutuhkan untuk melaksanakan beberapa tugas yang merupakan pengembangan dari hasil training dan pengalaman yang didapat.

Kepemimpinan adalah kemampuan untuk mempengaruhi pihak lain dan keberhasilan seorang pemimpin tergantung kepada kemampuan untuk mempengaruhi itu. Anoraga (2003: 2) menjelaskan bahwa kepemimpinan adalah kemampuan seseorang untuk mempengaruhi orang lain melalui komunikasi, baik langsung maupun tidak langsung.

Gibson (dalam Wirawan, 2013: 6) menjelaskan bahwa kepemimpinan adalah suatu upaya penggunaan pengaruh bukan paksaan untuk memotivasi orang-orang untuk mencapai tujuan tertentu. Sedangkan Hadari, (1993: 9) menjelaskan bahwa 
kepemimpinan merupakan kemampuan atau kecerdasan mendorong sejumlah orang (dua orang atau lebih) agar bekerjasama dalam melaksanakan kegiatan-kegiatan yang terarah pada tujuan bersama.

Dapat ditarik kesimpulan bahwa keterampilan kepemimpinan adalah kemampuan mempengaruhi seseorang atau kelompok. Kemampuan tersebut berasal dari pengembangan hasil training dan pengalaman yang didapat sehingga tujuan yang dicita-citakan dapat tercapai.

Ohlesun (dalam Wibowo, 2005: 18) menyatakan bahwa layanan konseling kelompok merupakan pengalaman terpenting bagi orang-orang yang tidak memiliki masalah emosional yang serius. Melalui proses konseling kelompok, siswa dapat memadukan segenap kekuatan dan kemampuan untuk mengatasi permasalahan yang dihadapi. Thomson dan Rudolph (dalam Prayitno, 1995 : 112) menjelaskan bahwa tujuan konseling kelompok dapat terentang dari sekedar klien mengikuti kemauan-kemauan konselor sampai pada masalah pengambilan keputusan, pengembangan kesadaran, pengembangan pribadi, penyembuhan dan penerimaan diri sendiri.

Berdasarkan pengertian layanan konseling kelompok dapat disimpulkan bahwa konseling kelompok merupakan salah satu layanan bimbingan dan konseling, yang diselenggarakan dalam kelompok yang memanfaatkan dinamika kelompok untuk membahas suatu masalah hingga tuntas. Kegiatan layanan konseling kelompok ini untuk membantu memecahkan dan mengentaskan permasalahan pribadi yang dibahas bersama anggota kelompok secara tuntas.

Bandura (dalam Susati, 2013: 17), yang dimaksud strategi modelling adalah suatu strategi dalam konseling yang menggunakan proses belajar melalui pengamatan terhadap model dan perubahan perilaku yang terjadi karena peniruan. Menurut Corey (dalam Sutanti, 2015: 192) istilah pemodelan dapat di artikan sebagai belajar dengan mengamati, menirukan, belajar sosialisasi, dan belajar dengan menggantikan. Teknik modelling adalah bagian dari terapi behavior. Teknik behaviour berfokus pada perilaku yang terlihat dan penyebab luar yang menstimulasinya. Behaviour memandang manusia sangat mekanistik, yang menjelaskan mengenai stimulus-respons seolah-olah manusia akan bergerak atau melakukan sesuatu apabila ada stimulusi (Hidayat, 2011: 127). 


\section{Metode Penelitian}

Desain yang digunakan dalam penelitian adalah pre-experimental, yang dilakukan dengan memberikan perlakuan (treatment) tertentu dengan subjek penelitian (one group pretest-posttest design). Jadi subjek dikenakan dua kali pengukuran. Dengan demikian perlakuan dapat diketahui lebih akurat, karena membandingkian hasil yang diperoleh sesudah perlakuan dengan keadaan sebelum diberi perlakuan.

Perbedaan antara pre-test dan posttest diasumsikan sebagai efek dari treatment atau eksperimen. Desain tersebut digambarkan sebagai berikut:

\begin{tabular}{|llll}
\hline $\mathrm{T} 1$ & $\mathrm{X} \longrightarrow \mathrm{T} 2$ \\
\hline
\end{tabular}

\section{Gambar 1.1 Desain Penelitian}

Keterangan :

T1 : Pre-test (tes sebelum konseling kelompok)

$\mathrm{X}$ : Treatment (pemberian konseling kelompok)

T2 : Post-test (tes sesudah konseling kelompok

Populasi merupakan keseluruhan objek atau subjek yang berada pada suatu wilayah dan memenuhi syarat tertentu berkaitan dengan masalah penelitian. Populasi juga dapat didefinisikan sebagai keseluruhan unit atau individu dalam ruang lingkup yang akan diteliti (Martono, 2014: 76). Populasi dalam penelitian ini adalah siswa kelas X D SMKS 16 Farmasi Bhakti Nusa Bengkulu.

Sampel yang digunakan dalam penelitian ini berjumlah 7 siswa dengan kriteria siswa yang keterampilan kepemimpinannya rendah. Teknik pengumpulan data menggunakan angket dan teknik analisis data menggunakan uji validitas, uji reabilitas dan uji hipotesis.

\section{Hasil dan Pembahasan}

Analisis hasil pre-test dan pos-test keterampilan kepemimpinan siswa kelas $\mathrm{X}$ D SMKS 16 Farmasi Bhakti Nusa Bengkulu.

Tabel 1. Katagori Pre-test

\begin{tabular}{ccc} 
Interval & Frekuensi & Kategori \\
\hline$>164$ & 12 & Sangat tinggi \\
$148-163$ & 14 & Tinggi \\
$132-147$ & 4 & Sedang \\
$99-131$ & 5 & Rendah \\
$<98$ & 2 & Sangat rendah \\
Total & 37 & \\
\hline
\end{tabular}

\section{Pre-test.}

Hasil pengambilan data awal (pretest) tentang keterampilan kepemimpinan, diperoleh 12 orang siswa yang dikategorikan memiliki keterampilan kepemimpinan sangat tinggi, 14 orang siswa memiliki keterampilan kepemimpinan tinggi, 4 orang siswa 
memiliki keterampilan kepemimpinan sedang, 5 orang siswa memiliki keterampilan kepemimpinan rendah dan 2 orang siswa yang memiliki keterampilan kepemimpinan sangat rendah. Sampel yang termasuk dalam kategori sangat rendah dan rendah keterampilan kepemimpinannya diberi treatment berupa konseling kelompok dengan teknik modelling.

Hasil analisis data deskriptif pre-test terhadap 7 siswa yang menunjukkan keterampilan kepemimpinannya rendah dan sangat rendah. Siswa yang dijadikan sampel dalam penelitian ini merupakan gambaran kecil dari masalah rendahnya keterampilan kepemimpinan di kelas X D.

Berdasarkan informasi dari guru pembimbing, ada beberapa siswa yang memiliki tingkat keterampilan kepemimpinan rendah, bisa disebabkan oleh berbagai macam faktor. Salah satunya yaitu rendahnya kepercayaan diri siswa dalam menyampaikan pendapat, yang membuat siswa tidak aktif pada saat belajar, dan pada akhirnya mempengaruhi hasil belajarnya. Penyebab rendahnya keterampilan kepemimpinan siswa adalah karena siswa merasa malu dan takut dalam menyampaikan pendapat, kurangnya rasa percaya diri, dan sulit dalam menyesuaikan diri di dalam kelompok.
Sebelum diberikan layanan konseling kelompok dengan teknik modeling, diketahui dari hasil angket pretest yang diberikan di kelas X D terdapat 7 siswa dengan skor tergolong rendah dan sangat rendah dari pada siswa yang lain, siswa tersebut terdiri dari 5 orang siswa berada pada kategori rendah dan 2 orang siswa berada pada kategori sangat rendah. Siswa dengan keterampilan kepemimpinan yang rendah cenderung kesulitan menyesuaikan diri dengan lingkungan, misalnya kurang dapat mengungkapkan maksud dan keinginan kepada teman, malu, tidak berani mengeluarkan pendapat dan pendiam. Ketujuh siswa tersebut diberikan perlakuan (treatment) berupa konseling kelompok dengan teknik modelling.

Tabel 2. Katagori Post-test

\begin{tabular}{ccc}
\hline Skor & Jumlah siswa & Kategori \\
\hline$>164$ & 4 & Sangat tinggi \\
\hline $148-163$ & 3 & Tinggi \\
\hline Total & 7 & \\
\hline
\end{tabular}

\section{Post-test}

Berdasarkan hasil pos-test yang menggambarkan adanya peningkatan keterampilan kepemimpinan siswa yaitu 4 orang siswa menjadi sangat tinggi dengan persentasenya sebesar $57.1 \%$ dengan interval (>164). Tingkat keterampilan kepemimpinan tiga orang siswa menjadi 
tinggi, dengan persentasenya sebesar $42.9 \%$ dengan interval (148-163).

Setelah diberikan layanan konseling kelompok dengan teknik modelling, terjadi peningkatan keterampilan kepemimpinan siswa. Hal ini terlihat dari hasil post-test yang telah diberikan, dari 7 orang anggota kelompok yang sebelumnya masih tergolong sangat rendah 2 orang siswa dan 5 orang siswa tergolong rendah, menjadi 4 orang siswa berada pada kategori sangat tinggi dan 3 orang siswa berada pada kategori tinggi.

Perubahan skor tersebut karena dalam konseling kelompok dengan teknik modelling dibahas berbagai topik yang berkaitan dengan kepemimpinan siswa yang merupakan kisi-kisi angket. Teknik modelling dapat membuat siswa belajar melalui pengamatan yang dia lakukan. Treatment yang dilakukan peneliti adalah sebanyak lima kali pertemuan. Topik pemberian informasi yang diberikan oleh peneliti dalam konseling kelompok dapat mendorong pengembangan perasaan, pikiran, reaksi tubuh, dan tingkah laku yang efektif bagi anggota konseling kelompok, sehingga mereka dapat melakukan pendekatan personal secara berkelanjutan.

Teknik modelling yang dilakukan peneliti berupa proses pemberian model atau contoh melalui vidio. Teknik ini mengajarkan kepada siswa untuk mampu berpikir serta mengamati model yang ditampilkan sehingga perubahan perilaku dapat terjadi karena adanya peniruan.

Setelah mengikuti kegiatan konseling kelompok teknik modelling ini siswa mampu mengubah pandangan yang tidak bisa menjadi bisa dan yang terpenting adalah agar tercapainya tujuan untuk menjadi seorang pemimpin, paling tidak mampu memimpin dirinya sendiri. Siswa mampu mempersiapkan diri dan menghilangkan rasa takut, cemas, serta gugup pada saat berbicara di depan umum, kemudian dirinya mampu menjadi pribadi yang mandiri serta mampu menyampaikan pendapat dan memberikan kontribusi di dalam kelompok serta mampu menyesuaikan diri.

Tabel 3. Uji Z

\begin{tabular}{llr}
\hline No. & & Pretest-Posttest \\
\hline 1. & $Z$ & $-2.366^{\mathrm{a}}$ \\
2. & $\begin{array}{l}\text { Sig. (2- } \\
\text { tailed) }\end{array}$ & 0.018 \\
\hline
\end{tabular}

\section{Uji Hipotesis}

Berdasarkan taraf signifikansi (2tailed) adalah 0.018. Itu berarti nilai signifikansi (2-tailed) $0.018<0.05$. Kriteria penerimaan atau penolakan hipotesis itu berarti Ho ditolak dan $\mathrm{Ha}$ diterima. Oleh karena itu dapat disimpulkan bahwa ada perbedaan yang signifikan keterampilan 
kepemimpinan siswa sebelum dan sesudah diberikan layanan konseling kelompok dengan teknik modelling pada siswa kelas $X$ D SMKS 16 Farmasi Bhakti Nusa Bengkulu.

Hasil uji hipotesis yang telah dilakukan menunjukkan signifikansi 0.018 $<0.05$ yang berdasarkan kriteria penerimaan atau penolakan hipotesis Ho ditolak dan Ha diterima. Dapat disimpulkan bahwa ada perbedaan keterampilan kepemimpinan sebelum dan sesudah diberikan layanan konseling kelompok dengan teknik modelling pada siswa kelas X D di SMKS 16 Farmasi Bhakti Nusa Bengkulu.

Hasil analisis data penelitian dari pretest dan post-test juga menunjukkan bahwa secara keseluruhan masalah rendahnya keterampilan kepemimpinan siswa menjadi lebih tinggi setelah mendapatkan perlakuan (treatment) dibandingkan pada saat sebelum mendapatkan perlakuan (treatment). Hal ini diungkapkan anggota kelompok dari yang tidak bisa menjadi bisa, seperti halnya siswa merasa malu dan takut salah dalam memimpin serta dalam menyampaikan pendapat. Dapat disimpulkan bahwa pemberian konseling kelompok teknik modelling sesuai dengan prosedur, cukup efektif untuk meningkatkan keterampilan kepemimpinan siswa. Hasil tersebut berdasarkan tujuan konseling kelompok yaitu untuk mendorong pengembangan perasaan, pikiran, persepsi, wawasan dan sikap yang menunjang perwujudan tingkah laku yang efektif, yakni peningkatan kemampuan berkomunikasi, baik verbal maupun non verbal para siswa (Prayitno, 2004: 2).

Tujuan konseling kelompok menurut Prayitno (1995: 179) adalah setiap siswa: (1) mampu berbicara di depan orang banyak, (2) mampu mengeluarkan pendapat, ide, saran, tanggapan, dan perasaan kepada orang banyak, (3) belajar menghargai pendapat orang lain, (4) bertanggung jawab atas pendapat yang dikembangkannya, mampu mengendalikan diri dan emosi, (6) dapat bertenggang rasa, (7) menjadi akrab satu sama lain, (8) membahas suatu masalah yang dirasakan menjadi kepentingan bersama.

Salah satu tujuan layanan konseling kelompok seperti yang telah dijelaskan, salah satunya adalah membahas suatu masalah atau yang dirasakan menjadi kepentingan bersama, terjadinya saling hubungan antara anggota kelompok sangat diutamakan, karena dalam layanan konseling kelompok semua anggota mendapatkan kedudukan yang sama untuk saling berhubungan atau berinteraksi 
dengan anggota lain. Dengan demikian, konseling kelompok bertujuan untuk memberikan kesempatan kepada siswa untuk dapat saling mengenal satu sama lain, jujur dan terbuka, sekaligus dapat meningkatkan kepercayaan kepada orang lain dengan memanfaatkan dinamika kelompok.

Alasan penulis menggunakan teknik modelling, sebagai strategi pemecahan masalah yang dialami oleh anak. Bahwa dalam kegiatan kegiatan konseling kelompok kepada anak hendaknya disertai contoh, tidak hanya dengan teori saja sehingga mereka mampu mengamati serta memahami apa yang diinginkan oleh konselor dan terjadi perubahan prilaku karena adanya peniruan (modelling). Teknik modelling adalah suatu teknik untuk membantu klien belajar mengubah perilakunya melalui suatu contoh dan pengamatan terhadap model yang dikehendaki. Kegiatan konseling kelompok menggunakan teknik modelling dirasakan tepat untuk meningkatkan keterampilan kepemimpinan pada siswa.

Pelaksanaan teknik modelling ini sesuai untuk dilakukan dalam layanan konseling kelompok. Dalam kelompok yang sudah terbentuk dalam konseling, penerapan teknik modelling akan mengkondisikan antar anggota kelompok saling menelaah, mengakrabkan, terbuka, mengungkapkan perasaan, dan menyelesaikan masalah yang ada dalam kelompok. Dengan melalui latihan teknik modelling ini, hubungan antar-individu dapat saling terbuka dan adanya siswa dengan keterampilan kepemimpinan rendah dapat teratasi dengan cara meniru model.

Siswa di sekolah diharapkan dapat mengembangkan kemampuan intelektual dan juga diarahkan supaya menjadi individu yang mandiri dan memiliki kemampuan memimpin yang baik paling tidak mampu memimpin dirinya sendiri. Siswa juga diharapkan dapat berkomunikasi dengan baik, yang diantaranya memiliki kemampuan berbicara, proses penyampaian ide, pendapat, pikiran, dan keahlian dari individu satu ke individu yang lain. Keduanya harus berjalan dengan seimbang. Dalam penelitian ini, konseling kelompok teknik modelling dapat memecahkan masalah siswa terutama masalah rendahnya keterampilan kepemimpinan yang dialami siswa SMKS 16 Farmasi Bhakti Nusa Bengkulu.

Selama 5 kali pertemuan yang sudah dilakukan, anggota kelompok semakin akrab dan mulai terbuka untuk berbagi cerita, pengalaman, dan informasi sehingga setiap pertemuan terjadi peningkatan atau perubahan. Dengan dinamika kelompok ini, 
individu menjadi terbuka pada diri sendiri dan terbuka kepada orang lain. Sesuai dengan uraian tersebut dapat disimpulkan bahwa ada perbedaan keterampilan kepemimpinan sebelum dan sesudah diberikan layanan konseling kelompok dengan teknik modelling pada siswa kelas X D di SMKS 16 Farmasi Bhakti Nusa Bengkulu. Hal ini menunjukkan bahwa layanan konseling kelompok dengan teknik modelling efektif untuk meningkatkan keterampilan kepemimpinan siswa.

\section{Kesimpulan}

Berdasarkan hasil penelitian yang telah dilakukan, dapat disimpulkan bahwa rendahnya keterampilan kepemimpinan yang dimiliki siswa sebelum diberikan layanan konseling kelompok dengan teknik modelling dari 37 siswa di kelas X D didapat 7 orang siswa mayoritas berada dalam kategori rendah. Setelah diberikan layanan konseling kelompok dengan teknik modelling, dari 7 orang siswa yang mengalami rendahnya keterampilan kepemimpinan, 5 orang siswa meningkat menjadi sangat tinggi dan 2 orang siswa tinggi.

Arttinya ada pengaruh dari treatment (perlakuan) menggunakan layanan konseling kelompok, serta efektif dengan menggunakan teknik modelling dalam membentuk keterampilan kepemimpinan siswa. Hal ini dapat dibuktikan dari hasil analisis data yang menyebutkan bahwa Ho ditolak dan $\mathrm{Ha}$ diterima yang berarti terdapat pengaruh layanan konseling kelompok teknik modelling dalam membentuk keterampilan kepemimpinan siswa.

\section{Daftar Pustaka}

Anoraga, (2003). Psikologi kepemimpinan. Jakarta: Rineka Cipta

Ariwibowo, R.N (2011). "Pengaruh kepemimpinan, motivasi, dan lingkungan kerja fisik terhadap kinerja karyawan". Skripsi: Universitas Diponogoro

Hidayat, (2011). Psikologi Kepribadian. Bogor: Ghalia Indonesia

Hurlock, (1980). Psikologi Perkembangan. Jakarta: Erlangga

Pahlawan, (2005). Kepemimpinan Islam dan Dakwah. Jakarta: Amzah.

Prayitno. (1995). Layanan Bimbingan dan Konseling Kelompok Dasar dan Profil. Jakarta: Rineka Cipta.

Rohadi, (2015). Keterampilan Dan Nilai Sebagai Materi Dalam Pendidikan. Http://iptekdakhlan.blogspot.com/201 2/09/keterampilan-dan-nilai-sebagaimateri.html.,diunduh 11 Juni 2017.

Susati, P. (2013). "Penerapan konseling kelompok dengan setrategi modeling simbolis untuk meningkatkan keaktifan siswa dalam layanan informasi". Jurnal BK Unesa 4,(1), 16-21. Diakses pada 18 Januari 2017. 
Sutanti, T. (2015).'Efektivitas Teknik Modeling Untuk Meningkatkan Empati Mahasiswa BK Universitas Ahmad Dahlan". Jurnal Psikologi Pendidikan 1,(2),188-198. Diakses pada 19 Januari 2017.

Wibowo. (2005). Pengaruh Layanan Konseling Kelompok terhadap disiplin belajar siswa”. Jurnal penelitian dan pendidikan. 8,(1),22$32 . \quad$ Diunduh dari http://Konselingkita.com /tanggal 18 Januari 2017.

Wirawan. (2013). Kepemimpinan. Jakarta: Raja Grafindo Persada. 